\title{
THE INSTITUTIONAL PERSPECTIVE IN ECONOMIC GEOGRAPHY
}

\author{
a perspectiva institucional e a geografia econômica
}

Rita Alcântara Domingues *

\begin{abstract}
This article presents a preliminary study of the institutional approach through the lens of economic geography. In the theoretical framework, the line of thought of Veblen (1965) and Douglass North (1993) on institutional economics is highlighted, recovering concepts such as institutions and organizations. The ideas which are specifically highlighted are Martin's $(1996,2000)$, being new economic geography, using the concepts of environment and institutional arrangement. These ideas are based on the recognition that the theoretical perspective which is adopted opens a possibility of analysis and understanding of long-term dynamics, contradictions and all necessary adjustments to structural change. Finally, it is deemed pertinent to consider the inclusion of the institutional approach in geographical studies as an alternative for understanding territory.
\end{abstract}

Key words: Institutional approach; Economic geography; Regional analysis; Spatial territory.

\section{Resumo}

Este artigo apresenta um estudo preliminar da abordagem institucionalista sob um olhar da geografia econômica. No arcabouço teórico, destaca o pensamento de Veblen (1965) e Douglass North (1993) sobre a economia institucionalista, resgatando conceitos como: instituições, organizações, e especificamente, na nova geografia econômica, estão ideias de Martin (1996, 2000), no que tange aos conceitos de ambiente e arranjo institucional. Pauta-se no reconhecimento de que a perspectiva teórica adotada abre uma possibilidade de análise e de compreensão da dinâmica de longo prazo, das contradições e dos ajustes necessários a toda mudança de caráter estrutural. Conclui que é pertinente considerar a inclusão da abordagem institucionalista nos estudos geográficos como alternativa para o entendimento do território.

Palavras-chave: Abordagem institucionalista; Geografia econômica; Análise regional; ordenamento do território.

\section{Resumen}

En este artículo se presenta un estudio preliminar del enfoque institucional en Geografía Económica. El marco teórico se destacan los puntos de vista de Veblen (1965) y Douglass North (1993) sobre la economía institucional, la elaboración de conceptos tales como instituciones, organizaciones, y en concreto, la nueva geografía económica. Estas son las ideas de Martin (1996, 2000), que utiliza los conceptos de medio ambiente y arreglo institucional. Con base en el reconocimiento de que la perspectiva teórica adoptada abre la posibilidad de analizar y comprender la dinámica de largo plazo, las contradicciones y los ajustes necesarios a los cambios estructurales de carácter. En conclusión, es conveniente considerar la inclusión del enfoque institucionalista en los estudios geográficos como una alternativa para la comprensión del territorio.

Palabras clave: Enfoque institucionalista, Geografía Económica, Análisis Regional, Organización Territorial.

(*) Prof ${ }^{a} \operatorname{Dr}^{\mathrm{a}}$ da Universidade Federal Rural de Pernambuco - Rua Dom Manoel de Medeiros, s/n, CEP: 52171-900, Recife (PE), Brasil. Tel. (+55 81) 33206455 - ritaalcantara@outlook.com 


\section{INTRODUCTION}

The need for the efficient use of water resources has led governments all over the world to be concerned about the management of such resources, especially through the development of regulatory mechanisms. In this context of concerns and international pressure, the Brazilian government reorganized the institutional framework related to water resources in recent years under Law $\mathrm{n}^{\circ}$. 9.433, on January 8th, 1997 (BRASIL, 2012).

The evolution of the Brazilian institutional setting regarding water resources went through various models; initially authoritarian and bureaucratic, characterized by State intervention in the construction of dams. This initially involved the IOCS (Inspectorate of Public Works to Combat Drought), which was transformed in 1919 into the IFOCS (Federal Inspectorate of Public Works to Combat Drought), and in 1945 to the Department of Public Works to Combat Drought (DNOCS). The Water Code of 1934 led to a more recent model, of a decentralized, participative system with the passing of the 1997 Water Law. In terms of the Code, there was only regulation of the articles related to the electricity sector, which impeded the full application of various other parts of the code.

The water system is an unbalanced equation, where, on one hand there is an increasing demand for multiple uses and on the other hand, there is the need for constant availability of water. Such an imbalance led Brazilian society to constitute a new institutional entity, capable of guaranteeing sustainability, with the Water Law of 1997. In order to understand the issue, institutional economics provides an alternative analytical perspective.

The analytical perspective of institutional economics understands the importance of considering institutions as possible agents of structuring and transformation, through the adoption of public policies capable of defining the uses and base material of the territory. Institutional economics considers that the structure of appropriation creates territory through the projection of interests and, in this sense, reclaims the concept of territory, as defined by Raffestin (1993, p. 143):

space and territory are not equivalent terms... space comes before territory. Territory is formed from space; it is a result of an action conducted by an actor at any level. Upon appropriating a space, concretely or abstractly, the actor territorializes the space.

Globally, Brazil is in a privileged position in terms of the availability of fresh water. However, various regions have problems, since the largest volume of water is located where the smallest part of the population and least economic activity is. Such differences bring the Brazilian semi-arid regions to the center of the discussion. Parallel to this, the São Francisco River is an example of the effective availability of water in the midst of relative scarcity throughout the Brazilian semi-arid lands.

The lower middle part of the São Francisco River has functions beyond the local area, reaching a regional dimension. This is due to the fact that its use is disputed between the actions of the Hydroelectric Company of the São Francisco (CHESF) with the generation of electricity and the Company of Development of the Valley of São Francisco (CODEVASF), with irrigation. Also, at the moment, under the jurisdiction of the federal government there is the Transfer of the São Francisco River Project. The disputes revolve around two factors: an ever increasing demand, with the pressure of new uses and the need for constant availability. These lead, of course, to the need to optimize water use, presupposing solid, integrated and coherent management in the administration of uses and conflicts.

In this case, however, the institutions are the common element for rational water use, allowing for transformations which generate sustainable economic growth.

When dealing with alternatives or regional development strategies, the economy offers the possibility for analysis through equations and abstractions from science itself. However, according to the authors of old institutional economics, such as Veblen (1965, p. 180-81), it is also possible to integrate the economy with other social sciences in a multi-disciplinary approach. This is the direction that this article will follow. 
Some methodological issues and theoretical instruments back up this analysis. This reflection highlights the theoretical framework developed by the economists Veblen and Douglass North (VEBLEN, 1965 and NORTH, 1990, 1992, 1993), regarding institutional economics. For the sake of clarity, some examples will be presented along with the theory.

Thus, the objective of this article is to deepen the study and understanding of institutional economics, observing its proximity and incorporation into economic geography for the analysis and understanding of territorial order. The question which guides this study is: "to what point does the use of the institutional approach through geography open up possibilities to analyze and understand reality"?

This article is based on a critical analysis of the historical, dialectic method and the premise that reality, as well as institutions, is not static, it is also contradictory and dialectic. In order to answer the question above, studies were carried out on institutional economics, drawing parallels between events, processes and institutions, as well as, logically, their influence on contemporary society and their correlation with the proposed concepts.

The paper is organized in two stages. The first regards the theoretical frame of the institutional issue through the lens of the institutionalists, discussing some concepts and their applications in other areas of knowledge, besides economics. The second stage analyzes the institutional perspective of economic geography and some propositions for its use. Finally, some final considerations will be given.

\section{THEORETICAL REFLECTIONS: VIEWS OF INSTITUTIONALISTS}

Some points of the conceptual bases of institutional economics, the origin of which is associated with the work of Veblen $(1898,1965)$, will be discussed, Following that, the contributions of the more recent New Institutional Economics (NIE) will be presented, linked principally to the concepts of Douglass North (1993). Besides this, there will be a focus on concepts such as institutions, property rights, transaction costs, adaptive efficiency and organizations, seeking, as much as possible, to illustrate them with examples.

\section{The Old Institutionalism}

In recent years, there has been an interest in institutions due to their importance in economic analysis, even though there is no agreement regarding how they should be dealt with, nor the implications of incorporating them. American institutionalists were the first to highlight the economic importance of the habits of behavior and thought of human groups. They also analyzed the economy and understood the complex role social institutions have in the economic dynamic. Veblen is considered the founder of the school of institutional economics, together with Commons and Mitchell.

Veblen's (1857-1929) institutional perspective has its origin in a movement of American thinking on political economics which was dominant between 1890 and 1940. This trend, which was influenced by the 19th century school of German history (Hildebrand, Knies and Schmoller), used concepts from psychology and British Darwinian evolutionism. It criticized the exclusion of institutions from the nucleus of the economy.

The key concept of Veblenian thought is in the very conception that an institution is a group of ideas, shared ways of thinking, and social habits which can be identified and changed in time and space. Thus, the institution would not have the materiality of an entity; rather, it would be defined by the very manner in which individuals conceive the organization of the shared life of the group.

In his work The Theory of the Leisure Class, (VEBLEN, 1965, p.178-179), Veblen links institutions to character types, in other words, to types of human beings. He establishes a relationship between them, since institutions select the most suitable types of humans. Individuals are selected to continue molding the institutions which have been inherited from the past, into their own likeness and image. In Veblen's thought, social structure is submitted to a process of evolution, in which a 
natural selection of institutions occurs. Roll (1962, p.445) admits that in this work, the problems of political economics have limited importance, presenting the cultural dimension as the main contribution of the analysis. However, to Veblen, a biological scheme prevails, using the Darwinian term "selection".

In Veblen's view, not only individuals are selected, he also recognizes the existence of a relationship between the institution and the need which gives rise to it. This results, nearly always, in a displacement of the institutions. This is a special point in the author's thinking regarding institutions, on which an explication of the conservative tendencies of societies is based. In other words, "institutions are products of past processes, adapted to past circumstances and consequently, are never in full accord with the demands of the present," (VEBLEN, 1965, p.181).

If his analysis is taken further, the institutions themselves are an element of social and psychological inertia and conservativeness. These are the characteristics of human beings who readjust their mental habits to conform to altered situations, but only 'after the fact,' and with reluctance. Veblen's main object of concern, based on this conception, is society. It becomes difficult to avoid the impression that he was actually more interested in the mental process which accompanies the workings of the economy.

According to Garrouste (1995, p.18-20), this is one of the reasons which led Veblen to advance theoretically and criticize pre-Darwinian economists, proposing a dynamic approach to reality. If a human action unfolds in a plural social reality, evolutionary economic science is research into cultural and institutional development, to the extent to which human beings or society are affected by economic and political demands.

Sunkel (1989, p.147) reiterates this idea, pointing out that this line of thought meant a radical break with Ricardo's classical political economics and his resulting laissez faire policies. Thus, the model signaled not only a criticism of dominant economics, marked by the analysis of mechanisms of balance, but also a differentiation of the contemporary approach to economics, to the extent to which it supported itself on the cultural and collective perspectives of institutions.

Another aspect that underpinned Veblen's (1919) reiterated criticism of neo-classical thought, was the false concept of human nature, since the individual was wrongly seen in hedonistic terms, as a socially passive, inert and immutable being (VEBLEN, 1898 apud GARROUSTE, 1995, p.19-20). This understanding had already gained strength by the end of the 19th century and the beginning of the 20th with the geographical paradigm of environmental determinism. Its exponent was Frederich Ratzel, who incorporated elements of Darwin's theory of the evolution of species to explain the matter of superior and inferior races, thus justifying European imperialism.

Veblen's methodology gives importance to the role that society plays in the definition of values, customs and formal institutions, without denying the interaction and feedback processes between the individual and society. Last, but not less important, according to Parada (2003, p.97), is the question of the adoption of the inductive method, following the pragmatic or instrumentalist philosophy of John Dewey.

As one moves forward in the analysis of Veblen's thinking, at first glance, the central theme of his theory of economic transformation is extraordinarily similar to that of Marx, according to Roll (1962, p.446-447). Like Marx, Veblen accentuates change and movement and builds a system based on a conflict between two forces. One of the poles of the process described by Veblen is technology, which should be considered as the sum of knowledge and skills. Institutions are at the other pole.

Other authors persisted with the critical trajectory of neo-classical economics. One in particular is Ayres, (apud MEHIER, 1995, p.62-65) who reinforces that institutions constitute an element through which economic systems can be analyzed.

Widening the vision of old institutional economics, Commons (apud BAZZOLI and DUTRAIVE, 1995, p.29-32) places the analysis of the production processes of behavioral rules through collective action at the center of economic theory. He does this in order to understand economic activities and capitalism. By elaborating new analytic categories, he moves the objective of econo- 
mic analysis from goods and individuals to what he calls "transactions". In his view, institutions become the headquarters of networks of regulated transactions in which the individual is both captive and actor.

According to Bazzoli and Dutraive (1995, p.37-38), Commons' great merit is having imagined this type of economic analysis. The understanding of institutional change presupposes not only a manifestation of an "innovations-conflicts" dialectic, but also a mutual adjustment of values. Among those who inspired the old idea of institutionalism is Mitchell (1874-1948), who was responsible for the embryonic theory of monetary economics and an implicit theory of the endogenous cycle.

From this perspective, economics is summed up, on one hand by dissatisfaction with the abstraction of neo-classical economics and the static aspect of the orthodox theory of prices. On the other hand, it is the demand for the integration of other social sciences, in a multidisciplinary approach.

In spite of theoretical advances, the dilemma of old institutional economics is due to the fact that it is difficult to present its conclusions using a group of equations, because of the complexity and subjectivity of the problems. In this case, its theories are informal, even though some scholars have made great efforts to formalize these ideas and build models.

One can say, then, that old institutionalism adopts a cultural conception of the formation and evolution of values and social behavior. It also highlights the dynamic role of technical progress, its contradictions with established institutions and social structures. It presents a historical and evolutive view of the process of socio-economic transformation, adopting society and its behaviors as the starting point for analysis. Great importance is given to power and the role of the State is emphasized, focusing on ideological and power systems expressed in political and governmental spheres as variables which determine the evolution of the development process.

\section{New Institutional Economics}

Although we recognize the relative importance of neo-institutional approaches, with different nuances and antagonism in relation to neo-classism, we opt to develop a deeper form of New Institutional Economics.

In the 1990s, a group of concepts and methods of economic analysis, which had been under elaboration for forty years, fit together like puzzle pieces, to compose what was called New Institutional Economics. Among the main theorists highlighted in this school, one can cite Douglass C. North, Ronald H. Coase, Gary Becker, James M. Buchanan and Williamson. In this article only three will be explored in detail, being North, Coase and Williamson.

New institutional economics considers the individual as the starting point for change, but differs by giving great importance to institutions. This includes highlighting formal and informal norms, laws and behavioral habits as fundamental. It is, however, the broadening of its postulates which will lead to a better understanding of the behavior of economic and political agents.

According to Martin and Sunley (2000, p.39-41), some neo-classical economists explained the differential of economic growth using exogenous factors, in the long term, between rich and poor countries, while others understood that such growth was due to endogenous factors.

North (apud PASSANEZI, 2002, p.16-17) became one of the precursors to relate institutions to the economic performance of nations. He sought to answer two questions: the first deals with the motives which cause countries to have such divergent growth trajectories; the second deals with the insistence of some countries, to continue on disastrous paths of growth. North links the answer to these two questions to binomial economic growth and institutions in each country. These 2 sentences are repeated verbatim in footnote 2

The analytical frame capable of increasing an understanding of the historical evolution of economies incorporates the institution and the temporal dimension in the investigation of the evolutionary games. Neo-institutionalists have put forth many ideas; however, the main character of the analysis involves the concepts of institutions, organizations, institutional arrangements, costs of transactions and the State. 
North (NORTH, 1993, p.1-3) began the outline of a new program of investigation which was increasingly supported by institutional arguments, such as the theory of transaction costs and property rights, to explain the complex problems of economic growth from a historical perspective.

In conceptual terms, North (1993, p.7) defines institutions as a set of rules, acceptance procedures and norms for moral and ethical behavior, all created to restrict the behavior of individuals. Political and economic institutions form the structure of incentives of a society and thus, are the fundamental determinants of economic performance. Time, the second category of analysis, is related to social and economic changes as well as building a dimension in which the process of learning (third category) takes place, thus favoring the development of institutions.

By broadening the concept of economic institutions, North points to the existence of implicit or explicit norms which regulate the adoption of decisions by the agents and limit, voluntarily or involuntarily, their decision-making capacity. These are what he calls formal rules (political and judicial rules, laws and constitutions) and informal rules (conventions, behavioral norms, habits of conduct, unwritten rules which are however, accepted). The importance of this last category is relevant since such rules are considered to be information passed down from generation to generation, forming part of the culture of a group of individuals.

North (1993) added that the institutions are also subject to changes but these occur in a different way. Formal institutions change over a shorter period of time and need the coercive action of the State in order to do so, whereas informal institutions do not require the coercive action of the State. They depend on the beliefs of their followers; society. Beliefs do not change over a short period of time; to the contrary, they take a lot of time to consolidate.

North also admits that the key to stable, sustainable economic and social growth and development is not only in the manipulation of macroeconomic variables, but also in the relationships between individuals in their everyday activities, those on the inside of companies and in State structures. (KALMANOVITZ, 2003, p.20).

Formal institutions are also seen from another analytical perspective, beginning with Williamson, who works with segmentation on two analytical levels. In the first, there are rules which operate mainly on the macro level, such as legislation which regulates a country. In the second, rules operate on a micro level, such as the internal rules of a company. Thus, one can see the multiplicity of elements which are found inside the definition of institution.

The contribution of authors such as Williamson (1993) is indisputable. He adds important points to this line of thinking, yet, according to some scholars, Coase's contribution was the most relevant, with the Transaction Cost Theory. In this theory, transaction costs tend to increase when the institutions are considered fragile. Searching to substitute the rationality in the explicative models, Williamson advances theoretically and shows that in a context where the market is insufficient, the institution imposes itself in the function of coordination. North (1993) goes beyond that and states that this theory can be a pertinent instrument for economic history as well as the analysis of institutional dynamics, in the process of economic growth and development.

They agree on the existence of interdependence and complementariness since informal institutions influence formal institutions. They define so-called property rights, which are the rights which owners have over a resource and which are guaranteed by the State.

The real estate rental market is a good example of this concept. When a governmental policy prioritizes all the rights of the tenant, to the detriment of the rights of the owner, these owners, lacking guarantees, decide not to make their properties available. With that decision, there will not be enough units available on the market. This generates transaction costs (another concept), and the possible availability to meet demand will be at higher prices. Following the concept, if safe contracts are not made possible, the exchanges will not occur or, in this example, there will not be enough rentals available. When negotiation does not take place, there are costs for both parties, whereas, if they made the exchange they could both benefit. 
However, when the government guarantees the legal rights of owners, based on safe contracts, the owners make their properties available and the market experiences stability, which also directly results in the lowering of prices.

The correction of this inefficiency in the rental market involves institutional changes which alter the benefits of the agents. North (1990) introduces the concept of adaptive efficiency, showing that institutions are more efficient if they have the power to adapt to institutional changes.

North extends his analysis to organizations, which, like institutions, provide structure for human interaction, but they are not to be confused. According to North (1993, p. 7-8):

[...] organizations are composed of groups of individuals united for a common purpose. Organizations are political (political parties, congress, regulatory agencies), economic (businesses, unions, cooperatives), social (churches, clubs, associations) and educational (schools and universities).

Beginning with this concept, North distinguishes between institutions and organizations. The former are the rules of the game. The latter are the players. Later he affirms that institutions determine organizations and at the same time, these affect the evolution of the institutions. In other words, when alterations occur, a situation of imbalance is temporarily generated which leads agents to rethink new organizations and institutions which are adapted to the current situation. Political or economic organizations compete to transform institutions to meet their interests. This means that organizations seek to maintain the status quo which interests them, or modify it according to their interests when the system of rules does not permit the resolutions of their conflicts or the realization of their objectives.

By extending the line of reasoning and building on the dialogue between theory and our reality, we can move toward regional planning for the semi-arid lands in Brazil, in terms of the use of water resources. It is possible to observe an institutional pattern in the territory of the São Francisco River in the northeastern semi-arid region. Three uses clearly reflect this pattern: the generation of electricity by the Hydro-electric Company of the São Francisco (CHESF); irrigation by the Company for Development of the São Francisco Valley (CODEVASF) and currently the transfer of the São Francisco River under the jurisdiction of the federal government.

Each is an organization with different plans of action, even though there is interdependency between them. This is so, because these organizations, although individualized, blend and complement each other. They move in parallel but touch at various times.

Specifically, the creation of CHESF represented the inaugural mark of a new stage in the development of the electricity sector, with the direct involvement of the State in the field. However, behind this action there was a far-reaching meaning, as the government's concern with the drought was no longer limited to social assistance and started focusing on region planning. In this situation it is possible to establish a dialogue with Veblen's ideas (old institutionalism) which recognize the existence of relationships between the institution and the need that gives rise to it, which nearly always results in a displacement of the institutions.

From this new perspective the government recognized the need to use the water which accumulated during the phase of hydraulic solutions, as well as using the water resources for other uses as a direct condition for economic development. Parallel to the creation of CHESF in the energy sector and inspired by the Tennessee Valley Authority (TVA), the Commission of the São Francisco Valley was born in 1948, after WWII. It was conceived to develop the Improvement Plan for the São Francisco Valley, which confirmed the importance of the use of the water from the São Francisco River for navigation (1952), irrigation (1950) and electricity generation.

Still regarding the regional picture, at a moment of significant importance in the role of these organizations, the Brazilian semi-arid lands experienced a great drought, from 1951-53. On this occasion the government moved to introduce changes, such as the creation of another agent, the Bank of the Northeast, designed to finance infrastructure in the region. However, in 1958, there was 
another serious drought. It served to show that solutions based on building dams, even though they were combined with actions of agencies such as the IFOCS (highways), were not enough to solve the problem of stagnation in the region. The correction of this inefficiency involved institutional changes which altered the benefits which agents received.

In that context, the Work Group for the Development of the Northeast (GTDN) was created. Following the orientation of Celso Furtado, the GTDN deepened the analyses in search of the real problems and solutions which would be implemented through a new organization, the Superintendence of the Development of the Northeast (SUDENE) at the end of the 1950s. One can see that new needs led to institutional changes and according to North's (1990) view, the institutions and organizations would become stronger according to their adaptation to the new institutional reality.

When industrialization is added to national strategies for development, as an economic alternative, energy must be consolidated and suitable to the regional developmental process. Through SUDENE, the transfer of part of the industrial capital of the Southeast to the Northeast should have been incentivized. Activities which would certainly lead to industrial growth should have been moved to the latter region to allow for more dynamism in the area.

Thus, it is possible to see that institutional patterns and economic performance walk hand in hand and can be a resource to understand the weight and importance of the actions of organizations in a specific region. However, this view occurs when concentrating attention on the adoption of strategies, norms and procedures which confer political and economic power to certain organizations. In this case, two are included. CHESF is the company which defined the use of water for electricity generation in the region and CODEVASF is the company which indirectly structured productive space with modern agricultural techniques of irrigation. Both were responsible for the territorial organization of the Brazilian semi-arid lands as well as the region of the São Francisco River.

This perspective allows not only an understanding of the institutional changes and the actions of organizations based on formal institutions, but also it opens up the possibility of analyzing and understanding the long-term dynamic, and the contradictions and necessary adjustments for the total change of the structural character.

\section{THE INSTITUTIONAL PERSPECTIVE IN ECONOMIC GEOGRAPHY}

Economic geography was seen for many years as a subdiscipline; according to Ron Martin (1996) it was only after WWII that it was carefully molded by economics. Throughout the 1980s, his studies were based on two basic research programs: the dynamic of industrial location and the process of unequal regional development, using concepts and theories from Keynesian and Marxist neo-classical economics. Their analyses, according to specialists, were, up to a certain point, in conflict with spatial economic reality, prioritizing scientific knowledge to the detriment of subjective knowledge based on introspection, perception and intuition. These analyses did not fit the perspective of the time and led to questioning and reformulation of the theories, premises and principles of modern economic geography and its two main research programs.

According to Martin (1996, p.33), this complete turnaround can be traced to three main interconnected sources of disruption. The first was substantive, occurring when many believed that a phase of "new economic realities" had arrived, capable of creating problems for the theories on spatial economics. The second potentializes the first, since economics found itself in a whirlwind, generally for the same reason. There was a crisis in economics. None of the main schools of economics - neo-classical, Keynesian or Marxist, adequately explained the events and changes of the previous two decades. As these paradigms were besieged, there was progress in revisions and reformulations. Thirdly, again according to Martin, if these other challenges were not enough, in economic geography as well as in the economy the epistemological and ontological bases of theoretical investigation were being contested. 
Thus, in light of these new "economic realities," none of the main schools of economics explained the events and changes of the past decades. So there was a need to rethink the theories, premises and principles of modern economic geography. According to Martin (1996, p. 39), as the nature and organization of capitalism changes, the content of the concepts also changes. Thus, attempting to apply the same concepts and theories to different eras of economic development is, at the very least, naive.

In this recent process of restructuring, the institutional perspective was incorporated into economic geography and maybe for this reason, this discussion finds itself on the fringes of this science. Yet, Martin (2000, p. 79) shows that, beginning in the 1990s, there was a recognition that the evolution of the economic scene cannot be understood without paying special attention to the various institutions on which it depends.

In order to meet these new challenges, concepts and theories must be suitable. For that to take place, a new work program is needed, centered on a process of rebuilding economic geography, which must be multi-dimensional, multi-vocal and from multiple perspectives. In the first case, the analysis begins with the different levels or fields of economic process. It emphasizes the interaction which is capable of producing a specific configuration of unequal development. For that to happen, according to Martin (1996, p. 56), at least four levels need to be considered: the microeconomy; the macroeconomy; the economics of capital and transnational finance; and the global economy. Each of these variables is partially dependent; no one level totally controls the others and no single level is completely independent of the others. Thus, there is a complementarity between them.

In this context, economic geography should perceive and conceptualize connections and understand how and why its interaction and relative importance vary from place to place. This is so, since the meaning of an economic event is modified by geographical scale and has its own dynamic, which is constantly being made and remade. Thus, in view of the complexity of the facts, one cannot make a reductive analysis or use a single theory to explain its specificity.

The constitution of territories is not limited to the existence of natural resources and infrastructure. If, on one hand, there is the recognition of the relative importance of natural resources for some activities, then on the other hand, nowadays the economic dynamic includes issues about the role, impact and evolution of institutions in the process of development and differentiation of the regions. This perspective does not mean, however, that an exclusive role is attributed to the institutions regarding the conditions of development, but that it understands the effects of the institutional regime on that process.

Economic geography is multidimensional and also has multiple perspectives and is open to a wide range of theories. According to Martin (1996, p. 56) economic geography should also be multi-vocal since it attributes importance to the different social groups which constitute the economy, rather than hiding them or grouping them in neutral categories and general types.

As was mentioned above, Martin (2000, p. 79) feels that economic activities can only be understood in the context of the social structure and within the group of rules and conventions which regulate that structure. In this sense, incorporating an institutional perspective into economic geography seeks to understand and analyze the different modalities through which institutions configure regions and create territories.

The foundation of this vision is in the evidence of the concepts of institutional environment and institutional arrangement. The first is understood as a formal and informal system of norms and conventions which acts as a support to the advantageous use of specific resources in the territory, allowing one to see the mechanisms of horizontal coordination for the different sectors of activity. The notion of institutional arrangement, in turn, denotes a specific form of organization, as in the case of specific regional planning. The agencies regulating water resources and the regional development companies (Chesf, Sudene, Codevasf) have supported the formation of the territory of the Brazilian Northeast. 
The importance of the use of these concepts in economic geography resides in the understanding of how economic organizations arise, function, evolve and create arrangements influenced by the institutional environment.

As seen above, there are two basic types of institutions in society: the formal and the informal. The first consists of the society's formal norms and laws, such as the Federal Constitution. In this case, a formal norm is the Law of Financial Compensation for the Use of Water Resources, related to the Brazilian electricity sector.

The payment is the amount which the holders of concessions or permits for power plants pay to the states, Federal District, municipalities and direct administrative organs of the State to exploit the water potential. The installations designated for the production of electricity are in these territories, or these are areas invaded by the waters from the reservoir; this is known as side payment and is a way of compensating for damages incurred, due to the environmental impact.

Municipalities which are involved in the process have received additional revenue since the institution and regulation of the side payment for the resulting exploration of petroleum, natural gas and water resources in order to generate electricity. This came about through Federal Law n. ${ }^{\circ}$ 7.990, on December 28, 1989, and Law n. ${ }^{\circ}$ 8.001, on March 13, 1990, and through Decree n. ${ }^{\circ} 01$, on September 11, 1991 (BRASIL, 2012).

The goal, which must not be lost from view, of encouraging dialogue between theory and reality did not bring the expected results. After a critical analysis of the changes in the population's living conditions, which would come from the availability of additional resources paid by the electricity sector to the municipalities located on the banks of the São Francisco River, the results obtained did not reveal a higher standard of living for the inhabitants. (DOMINGUES, 2012). However, in our understanding, the additional resources, if well invested would be a window of opportunity capable of minimizing the needs experienced by the population of the semi-arid.

Based on this analysis, the transfer of royalties from the electricity sector to these municipalities, the formal institution of financial compensation, seems to be inefficient in a variety of aspects. To begin with, there is no positive evidence of social or economic development as a result of the application of these resources which the cities receive. There is also a shortage of sufficiently strong control institutions to guarantee the use of these resources and to register the revenue and expenditure in municipal accounts.

Currently, the system used does not allow for social control and disrespects the government guidelines concerning transparency in the use of public funds. Considering that any constitutional transfer is subject to accountability, and that the legislation is omissive in this case, measures should be taken to revise the law which regulates financial compensation. This would seek to guarantee the effective use of the resources, as well as royalties from the electricity sector serving as a growth strategy for the recipient municipalities.

In this way, it is possible to go beyond a mere attempt at understanding, and not settle for a simplified, reduced image of this process. If the effective investment of these resources were applied to elementary education, it would be possible to purchase school books and supplies for the students and improve or implant basic sanitation in the schools. This would give people basic literacy skills, as well as giving them access to reading and writing. This would generate positive results throughout society.

Continuing this policy to improve the educational system using these resources, other parallel actions could be carried out, such as implanting a full school day; providing suitable infrastructure for the school system; adopting a process of selection, preparation and qualification of teachers and administrators and then giving them a more attractive salary; and finally guaranteeing investments in the quality of education as a priority of the State, especially at the elementary level.

This issue is important in the example and merits attention. If these resources were well utilized they could also promote a greater economic dynamism not only due to the existence of better 
human resources but also through investment in employment and income generating structures. So the correction of this inefficiency is fundamental, but it involves institutional changes.

There is, however, the need to go forward with such a correction, which would take place through institutional changes. Returning to North, if a change alters the benefits of a privileged group that has the power of veto, nothing will change. The system will remain unaltered and inefficient. However, if the group which loses the benefits does not have the power to veto the changes, society sees the resources being used more efficiently and constructively. This pertains to North's explanation about societies which make progress. They are the ones capable of perceiving points of inefficiency and manage to surmount them.

Another contribution of the institutional approach refers to the aspects of institutional durability and inertia. According to Martin (2000), these characteristics make change quite complex in time and space. They are, therefore, specific points which can generate disputes, conflicts and simultaneously illustrate the territorial-institutional trajectory such as mediation between the past, present and future and the developmental conditions of a certain region. Alternatively, as Amin (2000, p; 65) suggests, the regional scale represents the space of composition in which the institutions can restrict the actions of individuals and organizations, and guarantee the stability of a territorial trajectory.

As an illustration of the concept, in the lower middle part of the São Francisco River in the Northeastern semi-arid lands, organizations such as IOCS, IFOCS, DNOCS, Chesf, Bank of the Northeast, Sudene and Codevasf are in effect the agents who determine the framework for the use of water resources in the region. Their actions reveal the specific, accumulative nature of the infrastructure for water use and the crucial role of interdependence between economic sectors, which end up being exerted on water consumption. It is evident that the actions of these organizations are directed by formal institutions.

In this way, the changes proportioned by the dialogue between economic geography and the institutional perspective highlight the recognition of the role of territory as a component in the process of building specific resources. This implies, of course, interaction between economic and social agents, and their institutional environment.

\section{CONCLUSIONS}

The process of restructuring economic geography is not something new, unique or problematic in itself, but rather one more challenge to be faced. Life is not lived just moving from one phase of capitalistic economic development to another, but also, in the challenge of how we see and symbolize the world, from the relationship between our concepts and reality, no matter which meaning is used for the latter.

Institutional structures are understood as another analytical point of view, which function on a number of levels, interacting in different ways in time and space and their explanations are relative to the point in time and the place. For some, it would be a post-modern institutional economics, but the fact is that economic geography can benefit by incorporating and adapting premises and concepts from this approach in order to understand the regulating of territory.

The perspective of this paper allowed us to understand that the institutional approach opens up a possibility of analysis and of understanding the long-term dynamic of the contradictions and necessary adjustments in the changes of structural character.

It is considered, furthermore, as a new possible interpretation, associating the institutional environment to economic geography and its interaction with the economic, political, social dynamics and the role of the State in the management of territory. 


\section{REFERENCES}

AMIN, Ash. Una perspectiva instituticionalista sobre el desarrollo económico regional. Cadernos do IPPUR, Rio de Janeiro, v.14, n.2, p.47-68, 2000.

BAZZOLI, Laure.; DUTRAIVE, Veronique L'économie de l'action colletive de John Roger Commons. L'Économie Institutionnaliste: les fondateurs. V. Dutraive (Coord.). Paris, 1995, p.29-45.

BRASIL. Lei n. ${ }^{\circ}$ 9.433, de 8 de janeiro de 1997. Available at: <http://www.planalto.gov.br/ccivil_03/leis/ L9433.htm>. Accessed in: out. 2012.

BRASIL. Lei n. ${ }^{\mathbf{7}}$ 7.990, de 28 de dezembro de 1989. Available at: <http://www.planalto.gov.br/ccivil_03/ leis/L7990.htm>. Accessed in: out. 2012.

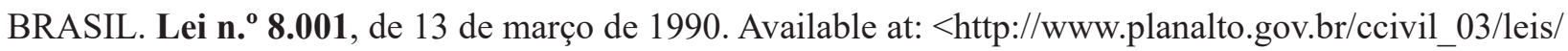
L8001.htm>. Accessed in: out. 2012.

BRASIL. Decreto n. ${ }^{0}$ 01, de 11 de janeiro de 1991. Available at: <http://www.dnpm.gov.br/conteudo.asp? IDSecao=67\&IDPagina=84\&IDLegislacao=39>Accessed in: out. 2012.

DOMINGUES, Rita Alcântara. Estratégia de crescimento? O caso dos royalties do setor elétrico. In: XVIII Encontro de Estudos Populacionais ABEP (Paper Presented). Available at:<www.abep.nepo.unicamp.br/ xvii/anais $>>$. Accessed in: out. 2012.

DUTRAIVE, Veronique. (Coord.). L'Économie Institutionnaliste: les fondateurs. Paris: Econômica, 1995, 109p.

DOMINGUES, Rita Alcântara. Aspectos institucionais da gestão dos recursos hídricos: o caso do Submédio São Francisco. 2006. Thesis (Doctorate in Geography) Universidade Federal do Rio de Janeiro, Rio de Janeiro.

GARROUSTE, Pierre. L'évolutionnisme de Thorstein Veblen. Léconomie Institutionnaliste. Les fondateus. Paris: Economica,1995, p.17-29.

KALMANOVITZ, Salomón. El neo institucionalismo como escuela. Revista de Economía Institucional, Colombia, v.5, n.9, p.189-215, 2003.

MARTIN, Ron; GREGORY, Derek, SMITH, Graham. (Org.). Geografia humana: sociedade, espaço e ciência social. Trad. MylanIsaack. Rev.técn. Pedro Geiger. Rio de Janeiro: Jorge Zahar, 1996, p.31-64.

MARTIN, Ron. Institutional approaches in economic geography. A companion to economic geography. London: Black Well Publishers, 2000, p.77-94.

MARTIN, Ron; SUNLEY, Peter. Convergência lenta: a nova teoria do crescimento endógeno e o desenvolvimento regional. Cadernos do IPPUR, Rio de Janeiro, v.14, n.1, p.15-48.

MEHIER, Caroline. Les apports de Clarence Edwin Ayres: place et rôle de la tecnologie dans la dynamique économique. L'Économie Institutionaliste: les fondateurs. V. Dutraive (Coord.). Paris: Economica, 1995, p.61-75.

NORTH, Douglass C. Desempeño económico en el transcurso de los años. In: Conferencia de North en Estocolmo, Suecia, el 09 diciembre, al recibir el Premio Nobel de Ciencias Económicas. 26p. Available at: $<$ http://www.eumed.net $>$. Accessed in: 03 mai. 2004.

NORTH, Douglass C. Custos de transação, instituições e desempenho econômico. São Paulo: Instituto Liberal, 1992. 38p.

NORTH, Douglass. C. Institutions, institutional change and economic performance. New York: Cambridge University Press, 1990.152p.

PARADA, Jairo. Economía institucional original y nueva economía institucional: semejanzas y diferencias.

Revista de Economía Institucional, Colombia, v.5, n.8, p.92-116, 2003.

PASSANEZI, Paula Soares Meyer. A evolução das instituições segundo Douglas North. 2002. Dissertation (Master in Economy) - School of Business Administration of São Paulo, Getúlio Vargas Foundation.

RAFFESTIN, Claude. Por uma geografia do poder. São Paulo: Ática, 1993. 269p. 
ROLL, Eric. História das doutrinas econômicas. São Paulo: Nacional, 1962. v.11, cap. 3: 72-109; cap. 9: 414-453.

SUNKEL, Osvaldo. Institucionalismo y estruturalismo. Revista de la CEPAL, Chile, v.38, p.147-156, ago. 1989.

VEBLEN, Thorstein. Sobre la naturaleza del capital. Revista de Economía Institucional, Colombia, v.2, p.197-216, 2000.

VEBLEN, Thorstein. A teoria da classe ociosa: um estudo econômico das instituições. São Paulo: Pioneira, 1965.

WILLIAMSON, Oliver. E. Transactions cost economics and organization theory. Berkeley: University of California, 1993. 58p.

Submitted april 2015

Accepted may 2015 